\title{
Americanism in Industry
}

\author{
By Rev. John A. RYan, D.D. \\ Professor of Moral 'Theology and Industrial Ethics, Catholic University of America
}

$\mathrm{T}$

HE traditional philosophy of American industrial life has assumed that almost, if not quite all, of the working class may confidently cherish the hope of some day becoming business men; for example, farmers, shop keepers, manufacturers, bankers. Most of us until quite recently have assumed that comparatively few workers need remain wage earners all their lives. A few years ago when the late John Mitchell declared that 90 per cent of the wage earners of today have no longer any definite hope of becoming anything else but wage earners, he was denounced by many newspapers as un-American. It was asserted that this philosophy was contrary to the philosophy and the facts of American life; but those of us who are willing to look facts in the face know that he spoke the simple truth.

The Laborer--A Wage Earner or a Business Man?

We call America the land of opportunity; it is, in comparison with other lands. This does not mean that practically all persons have the opportunity of selection of positions. Modern machinery in industry has created such a situation that if it continues to be dominated and owned, as it has been during the last fifty years, the great majority of the industrial population of this country will remain a class of wage earners and nothing else. The same is true, but not quite to the same degree, of the farm laborers. It is not nearly as easy now for a farm laborer to become a business man, that is to say, a farm owner, or even a tenant farmer, as it was twenty-five or thirty years ago; not that it is any more difficult to get a farm to rent -it is not-but the outlay and equipment required to carry on a farming business is greater today than formerly, owing to the greater importance and extent of machinery in the farming business. So this is the situation, that apparently the great majority of our population is due to remain merely wage earners during all of their working lives. Now, I maintain very positively that this is not a desirable nor a tolerable situation. I maintain that our ancient American industrial philosophy, the assumption that the majority may become business men to some degree, is a fundamentally sound philosophy. It is the only one that is going to endure. The opposite condition, in which all the owning functions and all the operating functions of industry are concentrated in the hands of a small minority, cannot be permanent. That is industrial autocracy pure and simple, and yet it is accepted as normal by probably the majority of the captains of industry.

\section{Autocracy and Stability iN INDUSTRY}

The theory appears in two forms. According to one form, the men who own and control industry should be unhampered in their operation and control of it, uninterfered with by any nuisance like a trade union with its collective bargaining and other disloyal methods. According to another form of the theory, trade unions should be permitted to function and to em- 
ploy collective bargaining, and there should be established certain minimum standards of welfare in industry which would enable the working class to have a fair living and, indeed, a fair amount of security against the contingencies of the future. Nevertheless, the adherents of both forms assume a sharp line of division between the two classes of the industrial population-at the top must be the owning and directing minority, and at the bottom the operating and executing majority, the men who are to be users of tools but nothing else.

Now, here is where the question of industrial stability comes in and the promotion of industrial stability. I do not think that we can have permanent industrial stability on the basis of that kind of industrial alignment or on any such industrial philosophy. Look at the essential contradiction of the thing. It means that the differences of interest, the opposition of interests between the two classes are over-emphasized, while the community of interest is minimized and ignored. The interests of capital and labor are different up to a certain point and they are common, or, at least, coöperative, beyond that point; but the evil of the present situation, the evil of this theory of industrial autocracy is that it is forever emphasizing the differences of interest and forever obscuring or minimizing or ignoring the community of interest.

Everybody is crying today for more production. The world needs a greater abundance of products, even this world of ours in America. How shall we prove to the working class that it is to their interest to produce more? You may say in the long run they will be better off if they increase their product. Of course, they will-in the long run. All of us will be better off in the long run if we obey the
Ten Commandments more consistently than is our practice, but the long run is the long run, and, therefore, its appeal is more or less remote. Practically, and for the present, and within the circle of interests that touch him in any vital and constant way, the laborer may find it to his interest to decrease production. The economists tell us that the "lump of labor theory" is a fallacy. So it is, considering the whole population, but it is not necessarily a fallacy for this particular group in these particular circumstances, any more than the creation of a manufacturing monopoly is a fallacy for the men who happen to have the monopoly. It is bad for the rest of the people, bad in the long run, but it is not bad for the owners.

This industrial autocracy, then, emphasizes the divergences of interest. It puts the laboring class in the position of constantly fighting for a greater share of the product and for better conditions of employment. It does not put emphasis at all upon their community of interest with the employing class, but accentuates the class conflict, and the demand for the overthrow of the whole capitalistic system. The working class more and more argues, "Since our interests are contrary to the capitalist's interest at all points, since he is the stumbling block to our getting the full product of labor, we must get rid of him entirely. Even Mr. Gompers talks about giving the laborer a larger share in what he produces. That assumes he is not getting all he produces now. But it is the capitalist who prevents him from getting all he produces. Therefore, the outcome of this feeling of diversity of interest is bound to be an increasing demand for an overthrow of the whole system, which means socialism. There is no industrial stability while this condition continues. 
The only fundamental method of industrial stability is that which will bring industrial America back to the position where it was before machine industry came, that is, to a condition in which there will be an actual opportunity for the majority, not necessarily for all, but for the majority of the workers to become in some degree business men.

The Function of the Business Man

Direction and Control of Industrial Processes.-The function or position of the business man has, as I see it, three important elements. The first is that of exercising direction, control, determining power over the industrial processes which he owns, the industrial processes in which he is engaged.

Pursuit of Indefinite Gains.-The next important element is the hope of getting indefinite gains as the result of hard work and efficiency. It seems to me that this is the soul of the theory of private capitalism. Government does not say to the private capitalists or private employers or private business man, "We are going to restrict your profits." It may penalize them through excess profits taxes, but, after all, that is not placing a limit on the amount of profits that they can make. The government says to the business man, in effect, "Go ahead, make all the profits you can. We shall not restrict the amount of them. We assume that as the result of this liberty of making indefinite profits which we give you, you will devise all kinds of schemes for improving production, and for cheapening production, so that in the long run the community will be benefited through the lower prices which they pay for commodities." On the whole, that theory has worked out pretty well, but the trouble is now that so many limitations have been set to it, so many obstacles in the form of monopoly and trade agreements between people who otherwise ought to be competing that we wonder whether the theory is working now or not. In any case, the freedom given to the manager, to the business man, to make indefinite profits which will depend on his own efforts, is the greatest incentive in the world to work.

Social Power and Security.-The third element in the position of the business man is the social power which comes from the fact that he owns property, the self-respect, the security, the self-reliance which are created and kept alive by the possession of propererty, and which cannot be produced by any other means.

\section{Is It Possible for Labor to Possess the Business Man's Advantage?}

These then are the three elements in the position of the business man: direction and control of industrial processes; the pursuit of indefinite gains which depend on his own achievements; and the social power and security that derive from the possession of productive property. It is possible for the laboring class, or the majority of them, to become business men, even with the industrial equipment that we have-with those immense machines, with our immense industrial units. The laboring class can be introduced to the first function, can obtain the first element of the business man's position through labor participation in management, through such devices as the shop committee and works council. I think that this is the most hopeful development that has occurred in a long time. Thereby the laborer will become possessed of the first advantage of the business man-the direction of some of the industrial processes in which he is engaged. He will get the opportunity to exercise some of his directive facul- 
ties, instead of being restricted to the exercise of the merely obedient faculties. He will direct some of the industrial conditions which surround him, instead of merely being a carrier out of orders that are handed to him by others. As Dr. Meeker so happily said in a paper that he read before the American Economic Association meeting last December, the psychology of the laborer is not essentially different from the psychology of the employer; "that's exactly what ails him." The great majority of American wage earners still have this inherent power and the desire to exercise it. This faculty is not yet atrophied in the laboring class in the United States.

\section{Labor's Participation in Management}

I was brought up on a farm. My father and his neighbors had to work very hard. The farmers were not making any such money in those days as they have been making recently, according to newspaper accounts, and many of these men could have made a better living if they had gone into the city and become wage earners. They felt that in spite of the hard conditions in which they lived, in spite of all the uncertainty of their position, they were, after all, free men, that they had something to say about the conditions in which they worked. While they complained about being at the mercy of the grain elevator sharks and the storekeepers in the city, and many other oppressors, they knew that there were certain large spaces in which they were determining their own lives. They were not taking orders from somebody else. They were not working according to some standardized scheme of life that somebody else had organized for them. These men were almost illiterate. They could read and write and do a little figuring, but they had an innate desire to direct their own economic life. It has always seemed to me that they were typical of the people who work hard with their hands, inasmuch as this desire which they had to be their own bosses, as they would say, is a desire that is shared by almost every normal person. The outlet or the opportunity for expression which labor participation in management gives to that fundamental desire is in itself of tremendous importance.

The second element or advantage of the business man's position, that of hoping for indefinite gains which will depend upon his own efforts, can be given to the laboring man, put within his reach, through the device of profit sharing. Profit sharing, as you know, is a very large and complex subject, but the thing is feasible; it has been proved so by almost every employer who has undertaken it in the right spirit, and who has not adopted it as a substitute for wages, or a means of keeping out unions, or for any other sinister purpose. It has been successful wherever it gave sufficient incentive to the laborer to enlist his energy, to enlist his capacity for hard work. If the theory which I have said is the soul of private management of industry, the theory that the business man should have the hope of indefinite gains dependent upon his own efforts, is good for him, why is it not good for the rank and file of workers? They are not different from the employer. As Dr. Royal Meeker says, they have the same kind of psychology as the employer. Then why is it not a good thing to hold out to them the hope of getting something in addition to their wages, provided they produce it?

Finally, the third and most important element in the business man's position, that of actual ownership of property, together with all the social advantages and power and self-respect which it brings, can be brought within 
the reach of the laboring class gradually, through labor participation in stock ownership of large corporations, and through out and out complete coöperation in the ownership and management of industries that are susceptible to that arrangement. Since it has been proved possible for the working classes to carry on great coöperative stores and wholesale stores, and the factories which the wholesale stores own, I see no essential reason why the laboring people should not be capable of carrying on coöperative factories. There is not any essential difference, as regards the qualities requisite for successful management.

These changes cannot be brought about in a day or a year, and it is not important that they should. It is important to realize the direction that must be taken, it is important to realize that we cannot in this democratic America and in the twentieth century continue to maintain a system of industrial feudalism, because that, stripped of all its glamor, is the character of the present system. I do not think it is wise for us to try to reconcile ourselves to such a form of industrial society. We have to get back to the early American philosophy of giving everybody the chance to become a business man within the limits and in the way that I have indicated. There is no middle ground, it seems to me, between the theory that the workers shall have to become to some degree owners and managers, and the theory of industrial feudalism. Between the two theories I think I can see quite clearly which one is going to survive. Remember that there was a time when men thought that there were only a few super-men in existence who were capable of managing political affairs. That theory has disappeared completely, and I believe that the counterpart of it, the theory that there are only a few super-men who are capable of directing industrial affairs, will likewise disappear. 